
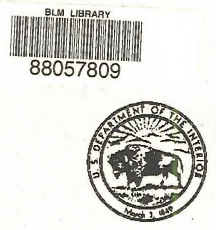

United States Department of the Interior

Bureau of Land Management

Las Cruces District Office

Caballo Resource Area

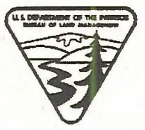

February 1994

\title{
RESOURCE MANAGEMENT PLAN AND RANGELAND PROGRAM SUMMARY ANNUAL UPDATE FY 1993-FY 1994
}

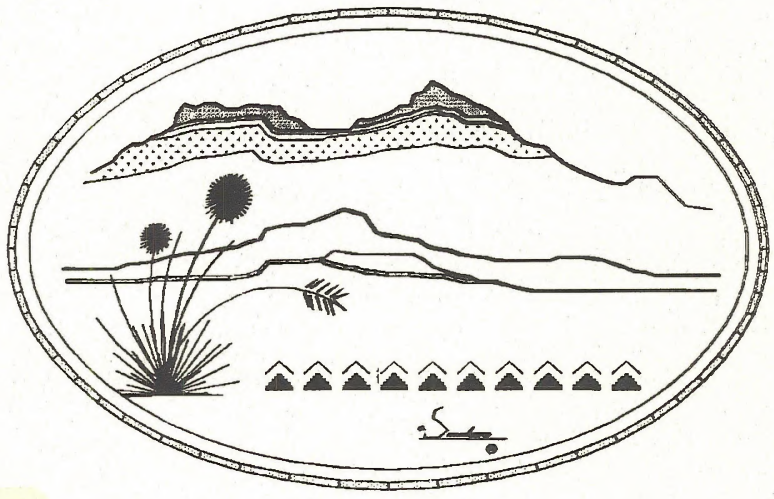




\section{BUREAU OF LAND MANAGEMENT}

The Bureau of Land Management is responsible for the balanced management of the Public Land and resources and their various values so that they are considered in the combination that will best serve the needs of the American people. BLM management is based upon the principles of multiple use and sustained yield; a combination of uses that takes into account the long term needs of future generations for renewable and nonrenewable resources. These resources include recreation, range, timber minerals, watershed, fish and wildlife, wilderness and natural, scenic, scientific and historical values.

BLM-NM-PL-94-0004-1600 


\title{
United States Department of the Interior
}

\author{
BUREAU OF LAND MANAGEMENT \\ Las Cruces District Office \\ 1800 Marquess St. \\ Las Cruces, New Mexico 88005
}

February 1994

Dear Reader:

This Resource Management Plan (RMP) and Rangeland Program Summary (RPS) Annual Update is part of the Caballo Resource Area's effort to keep the public informed of our ongoing multiple-use management programs. Open and effective communication and cooperation are fundamental to successful management of our public land. The intent of the Summary is to provide you information on the progress we have made during Fiscal Year (FY) 1993 and actions planned for FY 1994.

The Caballo Resource Area has made significant progress this past year in implementing positive management actions and planning future activities. To all those who are involved in helping us in this process, we wish to express our thanks and appreciation. We look forward to another productive year and encourage you to participate in the management of our public land.

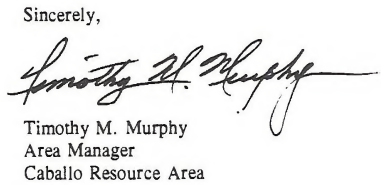




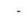


TABLE OF CONTENTS

PAGE

CABALlO RESOURCE AREA PROFILE $\ldots \ldots \ldots \ldots \ldots \ldots \ldots$

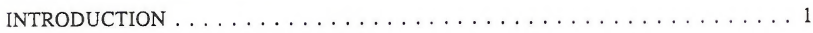

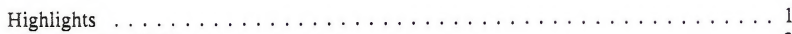

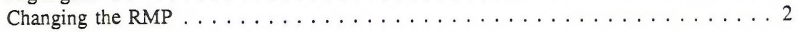

RESOURCE PROGRAMS IMPLEMENTATION ACTIONS

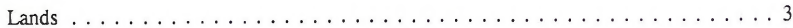

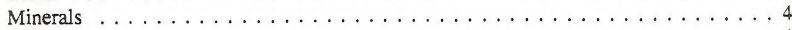

Rangeland Management . . . . . . . . . . . . . . . 4

Wildlife Habitat Management and Endangered

Species Management $\ldots \ldots \ldots \ldots \ldots \ldots \ldots \ldots \ldots \ldots \ldots \ldots$

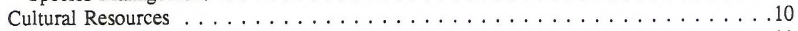

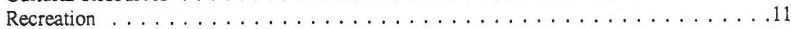

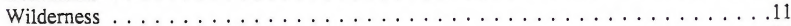

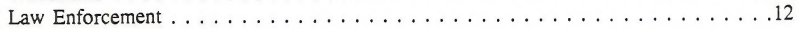

\section{APPENDICES}

Appendix A - Environmental Assessments $\ldots \ldots \ldots \ldots \ldots \ldots \ldots \ldots \ldots \ldots \ldots$

Appendix B - Rangeland Improvements $\ldots \ldots \ldots \ldots \ldots \ldots \ldots \ldots \ldots \ldots$ B-1

\section{TABLES}

Table 1 Completed and Planned Analysis/Interpretation/Evaluation

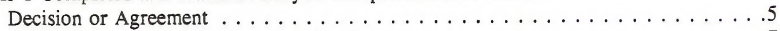

Table 2 1993-94 McGregor Range Grazing Contracts . . . . . . . . . . . . 7 
-

. 
CABALLO RESOURCE AREA PROFILE FOR SIERRA AND OTERO COUNTY

\begin{tabular}{|lcc|c|}
\hline \multicolumn{1}{|c|}{ LANDHOLDERS/MANAGERS } & SIERRA COUNTY & OTERO COUNTY & \multicolumn{1}{c|}{ TOTAL } \\
\hline Public Land & $1,109,905$ & $1,251,594$ & $2,361,499$ \\
Withdrawn Land & 538,036 & 944,752 & $1,482,788$ \\
Other Federal Land & 467,587 & 497,296 & 964,883 \\
Indian Land & 0 & 460,255 & 460,255 \\
State Trust Land & 361,195 & 449,908 & 811,103 \\
Private Land & 509,805 & 451,531 & 961,336 \\
TOTAL FEDERAL & $2,115,528$ & $2,693,642$ & $4,809,170$ \\
TOTAL ACREAGE & $2,986,528$ & $4,055,336$ & $7,041,864$ \\
FEDERAL MINERAL ESTATE & $1,749,514$ & $1,972,856$ & $3,722,370$ \\
\hline
\end{tabular}

\begin{tabular}{|c|c|c|c|}
\hline RESOURCE USES & SIERRA COUNTY & OTERO COUNTY & TOTAL \\
\hline
\end{tabular}

Areas of Critical Environmental

Concern (ACEC)

Acres

Developed Recreation Sites

(Three Rivers)

Annual Recreation Visits (FY 1993)

Wilderness Study Areas (WSAs)

Acres

Livestock Grazing

Allotments

Animal Unit Months (AUMs)

Operators

Allotment Management Plans

Oil and Gas Leases

Acres

Existing Recreation and Public Purposes Grants

Existing Rights-0f-Way

Wildlife Habitat Management

Habitat Management Plans

Acres

Coordinated Resource Management Plans Acres

Special Status Species
0

0

0

0

0

0

120

98,591

131

17

2

3,173

5

133

$$
\begin{gathered}
1 \\
417,000
\end{gathered}
$$

0

0

31

$\stackrel{2}{7,550}$

2

7,550

1 20,000

20,000

2

42,323

42,323

225

298,762

235

9

26

54

71,362

24

19

247

380

2 688,000

271,000

1
19,760

51

\section{19,760}

$64 *$

Yote: "Some species occur in both counties, some do not. The total species in the Resource Area is less than the sum of the county species. 


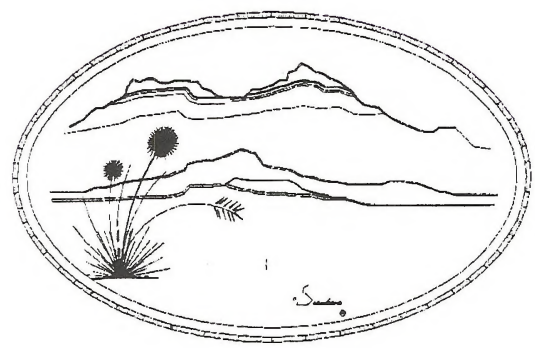

\section{INTRODUCTION}

This is the fourth White Sands Resource Management Plan (RMP) Update for the Caballo Resource Area. The purpose of this document is to update the public on implementation of the Bureau of Land Management's (BLM's) White Sands RMP. The RMP for the Caballo Resource Area (Sierra and Otero Counties) was completed in October 1986. Because implementation of the RMP will continue over a number of years, a RMP update document will be issued each year. The annual document will present information concerning the progress made in the previous fiscal year, and the actions planned for the current fiscal year to implement the RMP. This document presents the accomplishments for Fiscal Year (FY) 1993 and the planned actions for FY 1994.

The implementation actions (completed and planned) contained in this update are presented by resource program in the same sequence as the RMP (October 1986). The majority of the resource implementation actions are presented in simple list format with a short description.

PROGRAM NOTES are presented for resource programs which require more detailed discussion and provide information on routine actions.

The "Planned Actions" listed are actions that have been identified in the RMP for implementation in FY 1994. Project-specific developments (rangeland improvements and sign placements) are not listed as planned actions because these actions are site specific and were not specifically identified in the RMP.

All scheduled planned actions are projections based on current priorities and the budget for the fiscal year. If priorities and budget allocations shift during the fiscal year, the schedule for the planned actions may also change.

A list of the Environmental Assessments (EAs) which were completed in FY 1993 is also provided (see Appendix A). All EAs are available for public review at the Caballo Resource Area Office.

\section{HIGHLIGHTS}

On April 14, 1993, the New Mexico State Director designated the Lake Valley Back Country Byway. The Byway is located south of Truth or Consequences, New Mexico in BLM's Las Cruces District and includes portions of Highways 152 and 27. The Byway is designed to interpret mining and grazing history of the Lake Valley area. The Lake Valley Byway is an extension of the "Trails to the West" program that began in 
FY 1992. During FY 1994, three interpretive vehicle pullouts will be constructed, and an informational sign will be installed on each pullout along the Byway route.

Architectural stabilization designs were completed for the Lake Valley schoolhouse and chapel. Work on stabilizing a critical corner of the Lake Valley schoolhouse was completed. In addition, seven New Mexico State University (NMSU) public history graduate students began work on various projects associated with Lake Valley: a Lake Valley Back Country Byway brochure, a Lake Valley Self-Guided Tour brochure, and a traveling "museum kit" suitable for fourth and fifth grade curriculums.

The U.S. Bureau of Mines completed field work for the mineral inventory in the Caballo Resource Area during FY 1993. Coordination is in progress to develop a final report.

Two Recreation and Public Purpose (R\&PP) patents were issued to Otero County; one for a fire station and the other for a 20 acre park. Through the Rio Bonito Exchange, 8,927 acres of public land in the Caballo Resource Area were conveyed to the private sector. On McGregor Range, 1,007 acres of State trust land were acquired by exchange.

Work on the White Sands RMP amendment to consider six new Areas of Critical Environmental Concern (ACECs) was initiated. A pre-plan was developed which identified the following areas to be considered for ACEC designation: Sacramento Escarpment (expansion of the current designation), Alkali Lakes area, Cornudas Mountain, Wind Mountain, Alamo Mountain and Three Rivers. The formal undertakings of the amendment including public involvement will be conducted in mid-FY 1994. A North McGregor Coordinated Resource Management Plan was initiated. Vegetation/habitat inventory work began using satellite imagery to support the development of vegetation management goals and objectives.

The EA/EIS for the Fort Bliss Roving Sands 1993 and subsequent exercises was reviewed and commented on. Affects of the 1993 exercise were field checked and input provided to improve environmental protection. Coordination on the exercises is ongoing.

Law enforcement conducted patrol activities in Sierra and Otero Counties including McGregor Range. Resource area-wide activities consisted of 263 days of patrol and contacts with over 1,700 public land users.

As part of the Extended Monitoring Plan, 40 allotments were monitored to collect data for range conditions (ecological status), forage production, or forage utilization. Fourteen allotments, totalling 221,966 acres, were studied for range condition (ecological status). Trend in range condition (ecological status) was static on 149,233 acres and upward on 72,733 acres. A total of 84 allotments were visited by range conservationists to conduct use supervision to assure compliance with terms and conditions of the permit/leases.
The rainfall on McGregor Range was sporadic, however, by late August an average amount of 5 to 7 inches was received. Use supervision and range monitoring studies conducted indicated normal forage production, and the stocking rate for the 1993-94 grazing period was below average. A total of 27,000 animal unit months (AUMs) is contracted to graze McGregor Range from October 1993 through July 1994.

\section{CHANGING THE RMP}

The White Sands RMP is the guiding document for management of the public land resources in the Caballo Resource Area for the next 10 to 20 years. There are three techniques for changing the plan: plan maintenance, amendment, and revision. Plan maintenance includes correcting errors in the text, updating data bases, and correcting mapping errors. No decisions are changed through the maintenance processes. Plan amendments are major changes which affect one or more of the RMP decisions. Plan revision involves a complete rewrite of the RMP.

In FY 1993, there were no plan amendments scheduled for completion. A plan amendment will be initiated to consider six new ACECs in Otero County. The anticipated date of completion for this effort is FY 1995. One additional plan amendment may be scheduled during FY 1994 to address cultural resources management at Lake Valley. 


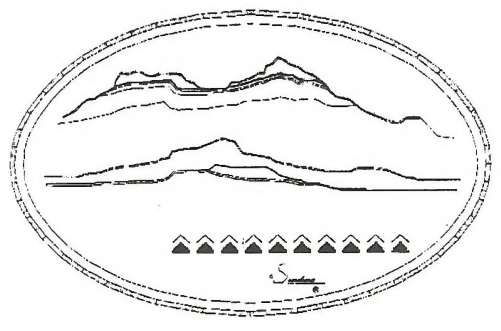

\section{RESOURCE PROGRAMS IMPLEMENTATION ACTIONS}

\section{LANDS}

\section{Accomplishments}

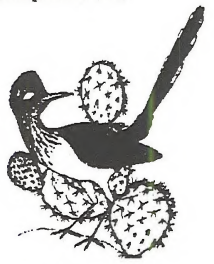

- Nine rights-of-way (ROWs) were processed in FY 1993.

- 1,007 acres of State trust land on McGregor Range were acquired by exchange.

- 8,927 acres of public land in the Caballo Resource Area were conveyed to the private sector through the Rio Bonito Exchange.
- Two Recreation and Public Purpose (R\&PP) patents were issued; one for a fire station to Otero County and one for a 20-acre park to Otero County.

- Land lines (survey) and land status data were entered into the Geographic Information System for Sierra and Otero Counties. This is 100 percent complete.

- A request for an 80 -acre sale is being processed.

- Three ROWs were obtained from the New Mexico State Highway Department to place kiosks for the designated Lake Valley Back Country Byway.

\section{Planned Actions}

- 960 acres of public land in the Caballo Resource Area have been identified for exchange in the Phase II Rio Bonito Exchange.
- Two R\&PP leased parcels will go to patent; a fire station for Sierra County and a rifle range for Otero County.

- One R\&PP lease will be issued for the City of Truth or Consequences, New Mexico Rifle Range. An R\&PP lease will be issued to the City of Alamogordo for the Desert Foothills Park.

- The 30-acre parcel for the addition to the City of Truth or Consequences landfill will be withdrawn. The old Truth or Consequences landfill request for purchase will be withdrawn.

- Holloman Air Force Base is sponsoring draft legislation to transfer up to 1,212 acres of public land to the Base for use in conjunction with a planned waste water treatment facility. 


\section{PROGRAM NOTES}

The Caballo Resource Area will continue to work on unauthorized use within Otero and Sierra Counties. The Resource Area anticipates 12 rights-of-way to be completed along with the routine public demand work.

Compliance examinations will be ongoing.

\section{MINERALS}

\section{Accomplishments}

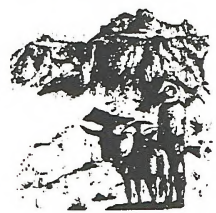

- The U.S. Bureau of Mines completed field work for the mineral inventory in the Caballo Resource Area during FY 1993. Coordination is in progress to develop a final report.

- A great deal of time was spent responding to public inquiries regarding implementation of the amendment to the 1872 Mining Law regarding the payment of rental fees for mining claims and related matters.

\section{Planned Actions}

- Initiate coordination with the State of New Mexico
Abandoned Mine Lands (AML) Program for an evaluation of safety needs regarding old mine workings at Lake Valley. This is a continuation of the Lake Valley Byway/Minerals Showcase Trails to the West initiative.

- Continue coordination with AML to complete an inventory of unsafe areas in the Jarilla Mountains and to develop plans to secure hazardous areas.

\section{PROGRAM NOTES}

Routine public demand workload processed through FY 1993:

\section{Mining Notices Processed 2* Mining Plans in Process 15 Mineral Materials Sales/Permits \\ 22 Oil and Gas Lease parcels were reviewed for National Environmental Policy Act (NEPA) documentation.}

The Omnibus Budget Act was enacted on August 10, 1993. This Act contained a provision for a $\$ 100$ claim maintenance fee and a $\$ 25$ location fee to be collected on all unpatented mining claims and sites through 1998.

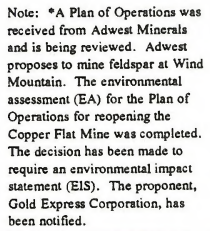

RANGELAND MANAGEMENT

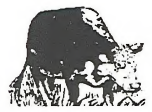

The Caballo Resource Area administers 225 grazing permits and leases covering 2,361,499 acres of public land. Active grazing preference for these permits and leases totals 298,762 AUMs. The price of an AUM for the grazing season (March 1 February 28) in 1992-93 was $\$ 1.92$ and for $1993-94$ is $\$ 1.86$, and has been set at $\$ 1.98$ for 1994-95.

\section{Monitoring Program}

The White Sands RMP assigned each grazing allotment into one of the following categories:

Category " $\mathrm{M}$ " allotments generally are in satisfactory resource condition; Category "I" allotments generally have the potential to improve resource conditions and resolve resource conflicts; Category " $\mathrm{C}$ " allotments generally have low resource production potential and are producing near their potential. Selected "M" allotments were also created and generally are in satisfactory resource condition; however, resource conflicts may. be occurring. 
TABLE 1

COMPLETED AND PLANNED ANALYSIS/

INTERPRETATION/EVALUATION (AIE)

DECISION OR AGREEMENT

\begin{tabular}{|c|c|c|c|c|}
\hline ALLOTMENT & YEAR & AIE & $\begin{array}{l}\text { DECISION/ } \\
\text { AGREEMENT }\end{array}$ & $\begin{array}{l}\text { MANAGEMENT } \\
\text { CATEGORY }\end{array}$ \\
\hline 07014 & 1993 & COMPLETE & AGREEMENT & I TO M \\
\hline 07037 & 1993 & COMPLETE & AGREEMENT & I TO M \\
\hline 09008 & 1993 & COMPLETE & AGREEMENT & I TO M \\
\hline 09032 & 1993 & COMPLETE & AGREEMENT & I Tо M \\
\hline 09040 & 1993 & COMPLETE & AGREEMENT & I TO M \\
\hline 09042 & 1993 & COMPLETE & AGREEMENT & I TO M \\
\hline 09058 & 1993 & COMPLETE & AGREEMENT & I TO M \\
\hline 09052 & 1993 & COMPLETE & AGREEMENT & 1 TO M \\
\hline 09056 & 1993 & COMPLETE & AGREEMENT & I TO M \\
\hline 09058 & 1993 & COMPLETE & AGREEMENT & I TO M \\
\hline 07022 & 1994 & PLANNED & & $\mathrm{M}$ \\
\hline 09036 & 1993 & PLANNED & & M \\
\hline 09045 & 1994 & PLANNED & & M \\
\hline 09046 & 1994 & PLANNED & & M \\
\hline 09059 & 1994 & PLANNED & & $M$ \\
\hline
\end{tabular}

The General Management

Guidance contained in the RMP essentially addresses the Selected "M" allotments the same as "I" allotments. Currently, there is a total of 111 "M" allotments, 25 Selected "M" allotments, 65 "I" allotments, and 24 " $\mathrm{C}$ " allotments.

Livestock grazing capacities for each "I" and Selected "M" allotments are to be evaluated. Last year an interdisciplinary Analysis/Interpretation/Evaluation (AIE) process was developed to determine not only proper grazing capacities, but to determine whether the goals and objectives of the RMP are being effectively achieved under current management. If the AIE concludes that the current stocking rate is proper, and the goals and objectives of the RMP are being met, then the allotment will be placed into the "M" category.

If the stocking rate requires an adjustment, and the goals and objectives are not being met, then the allotment will remain in the "I" category and management actions will be implemented to resolve the conflicts.

In conjunction with the AIE process, an Extended Monitoring Plan was developed which identifies the schedule for establishing baseline data, conducting use supervision, finalizing the AIE process, and issuing a Decision or Agreement for each allotment. Those allotments in which an AIE was completed in 1993 and planned for in 1994 are listed in Table 1. Decisions or Agreements which establish allotment goals and objectives will be issued the following year after the AIE is completed. In 1993, Agreements were issued on 10 allotments as shown in Table 1.

As part of the Extended Monitoring Plan, 40 allotments were monitored to collect data for 
range condition (ecological status), forage production, and forage utilization. Of this, 14 allotments totaling 221,960 acres were studied for range condition (ecological status). Trend in range condition (ecological status) was static on 149,233 acres and upward on 72,733 acres. A total of 84 allotments were visited by range conservationists to conduct use supervision to assure compliance with terms and conditions of the permit/leases.

\section{Grazing Activity Plans}

In 1993, two activity plans were developed on Allotments 06020 and 07022 encompassing a total of 83,300 acres of public land. Both activity plans were interdisciplinary, not only addressing grazing management, but also wildlife, watershed and riparian values. In 1994, it is planned to develop grazing activity plans on Allotments 16091 and 09036 encompassing 46,370 acres of public land.

\section{Rangeland Improvements}

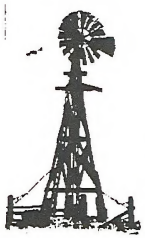

The development of the rangeland improvements is integral to the implementatio $n$ of the rangeland management

program on public land. Rangeland improvements allow BLM to apply management techniques such as pasture rest or deferment, improved grazing distribution, and brush control. Such improvements facilitate the achievement of resource objectives. All rangeland improvements are analyzed for their economic and environmental effects prior to implementation to ensure that resource objectives are achieved.

Implemented rangeland improvements for FY 1993 and those planned for FY 1994 are shown in Appendix B, and on pages 9 and 10 under Wildlife Accomplishments.

\section{McGregor Range}

Based on the Military Lands Withdrawal Act of 1986 (Public Law 99-606), BLM has continued to manage the natural resources within McGregor Range pursuant to the Federal Land Policy and Management Act of 1976. Based on a Memorandum of Understanding with the Department of Army and a RMP Amendment to the White Sands RMP for McGregor Range, BLM manages the livestock grazing program and maintains all rangeland improvements associated with this program on 271,000 acres of the Range.

Livestock are allowed to graze on the Range through a yearly competitive auction of grazing contracts for 14 grazing units. These contracts are bid on an AUM basis which is derived for each grazing unit from rangeland monitoring studies. Eleven contracts cover a 9-month period from October through June which allows for a 3-month growing season deferment, July through September, each year. This year, three grazing units were contracted for 18 month periods from October 1993 through March 1995. Although grazed through the summer of 1994 , each of these units will receive 6 months of deferment from April through September 1994. This back-to-back spring-summer rest is designed to benefit cool season grasses, forbs, and shrubs.

Fees collected from the grazing contracts are used to maintain rangeland improvements and conduct on-the-ground management and use supervision. Most of this effort is spent maintaining the 120 miles of water pipeline that provides the only permanent source of water in the grazing area of McGregor Range.

Table 2 summarizes the grazing contracts for the 1993-94 season.

Grazing Unit 6 no longer exists, however, the numbering of units was kept due to familiarity of units on the ground. In 1993-94. Units 4 and 5 were not offered. Water in these units continues to be available for wildlife.

In 1992, BLM received an appropriation of $\$ 380,000$ to replace portions of the pipeline critical to maintaining permanent sources of water for livestock and wildlife. Seventeen miles of the main pipeline were replaced with 2 and 3 -inch steel pipe which will increase amounts and efficiency of delivering water onto the mesa. Also, an additional 15 miles of plastic pipe have been replaced in the foothill areas, which is critical habitat for up to 4,000 mule deer. 
TABLE 2

1993-94 MCGREGOR RANGE

GRAZING CONTRACTS

\begin{tabular}{|c|c|c|c|c|c||}
\hline UNIT \# & $\begin{array}{c}\text { LENGTH OF } \\
\text { CONTRACT }\end{array}$ & $\begin{array}{c}\text { YEAR } \\
\text { INITIATED }\end{array}$ & AUMS & \$/AUM & TOTAL \\
\hline 1 & 18 Months & 1992 & 4,496 & $\$ 4.50$ & $\$ 20,232.00$ \\
\hline 2 & 9 Months & 1993 & 2,252 & $\$ 8.80$ & $\$ 19,817.60$ \\
\hline 3 & 9 Months & 1993 & 2,252 & $\$ 7.25$ & $\$ 16,327.00$ \\
\hline 4 & Not Offered & -- & -- & - & - \\
\hline 5 & Not Offered & -- & -- & - & - \\
\hline 7 & 9 Months & 1993 & 2,702 & $\$ 10.25$ & $\$ 27,695.50$ \\
\hline 8 & 18 Months & 1993 & 3,584 & $\$ 8.10$ & $\$ 29,030.40$ \\
\hline 9 & 8 Months & 1993 & 4,412 & $\$ 5.90$ & $\$ 26,030.80$ \\
\hline 10 & 18 Months & 1993 & 3,584 & $\$ 10.00$ & $\$ 35,840.00$ \\
\hline 11 & 9 Years & & & & \\
\hline 12 & 9 Months Each & 1990 & 3,150 & $\$ 4.00$ & $\$ 12,600.00$ \\
\hline 13 & 18 Months & 1993 & 4,488 & $\$ 10.25$ & $\$ 46,002.00$ \\
\hline 14 & 9 Months & 1993 & 2,252 & $\$ 8.25$ & $\$ 18,579.00$ \\
\hline 15 & 9 Months & 1993 & 901 & $\$ 11.55$ & $\$ 10,406.55$ \\
\hline TOTALS & & & 34,974 & & $\$ 271,706.00$ \\
\hline \hline & & & & & \\
\hline
\end{tabular}

In past years, approximately 35,000 AUMs were contracted for grazing on McGregor Range.

The 1993 summer rainfall was sporadic, but by late August an average amount of 5 to 7 inches was received. Use supervisions and range monitoring studies conducted indicated normal forage production, and the stocking rate for the 1993-94 grazing period was below average

as indicated in Table 2. A total of 26,898 AUMs (approximately 3,000 cattle) is contracted to graze on McGregor Range from October 1993 through June 1994. The units with 9-month grazing contracts will then be deferred from grazing through the growing season, July 1994 through September 1994 prior to contracting grazing in October 1994. A total of 8,076 AUMs will continue to graze as part of the 18-month contracts from July 1994 through March 1995. These grazing units will then receive spring plus summer growing seasons (6 months) deferment prior to being contracted again in October 1995. 


\section{Planned Actions}

The Coordinated Resource Management Plan is being developed for the foothills area that is represented by the piñon/juniper vegetation type.

This encompasses 50,000 acres in the northeast portion of

McGregor Range. The major focus of the plan will be to assess current conditions, develop objectives for wildlife habitat, watershed values and range resources, and to prescribe management actions to meet these objectives.

BLM will continue to replace and maintain water pipelines for use by wildlife and livestock. An emphasis in 1994 will be to replace water toughs. Plans are being made to rebuild 4 miles of fence and maintain 100 miles of road in 1994. Use supervision and rangeland monitoring will continue to ensure compliance with contracts and that proper use levels of forage are not exceeded.

BLM will continue to review and comment on the Army's EIS for Roving Sands, and other proposals brought forward by the Army. The proposed Roving Sands action is an annual military exercise of simulated surface to air warfare conducted partially on McGregor Range. Our effort will be to ensure that the resource management objectives contained in the McGregor Range RMP Amendment continue to be met, and the Black Grama ACEC and the Culp Canyon Wilderness Study Area (WSA) are protected.
WILDLIFE HABITAT MANAGEMENT/SPECIAL STATUS SPECIES MANAGEMENT

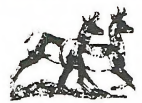

\section{Accomplishments}

- Monitored the Percha Creek Riparian Exclosure. A high intensity storm washed out the structure during the summer.

- Thirty wildlife projects were maintained.

- Two reservoir exclosures were completed using volunteer help (New Mexico State University Chapter of The Wildlife Society). Two others are ready for construction. The project was funded by Sikes Act Habitat Stamp funds.

- Two existing butyl rubber range/wildlife catchments were surveyed and re-designed as corrugated metal catchments to be constructed in FY 1994. This project will be funded by BLM 8100 funds and Sikes Act funds.

- Three riparian exclosures were surveyed and designed.

- The first of three annual aerial surveys for mule deer was conducted on the Brokeoff Mountains and the Cornucopia
Hills. The project was primarily funded by Sikes Act Stamp funds.

- The effects of wildfire on the Otero Mesa grasslands were monitored. Annual vegetative production (herbage weight) nearly doubled on burned areas.

- Input was provided to several grazing activity plans and allotment analysis efforts. Wildlife and riparian management objectives were incorporated into these plans where needed.

- Five special status species plants (Sacramento Mountain prickly poppy, Todsen's pennyroyal, Duncan's corycactus, Villard's pincushion cactus, and gypsum scalebroom) were monitored to detect management conflicts. A new colony of Todsen's pennyroyal was found. No conflicts were found.

- Inventory for the Guadalupe Mountain mescal bean in the Brokeoff Mountains was dropped due to designation as candidate Category 3 (no longer a candidate for listing). Approximately 1,000 acres of inventory for Guadalupe rabbitbrush, another candidate Category 2 species, was substituted. Two plants tentatively identified as Guadalupe rabbitbrush were found. 
- Preliminary planning to consider six new ACECs was initiated; however, most work was deferred to FY 1994. A pre-plan was developed which identified the following areas to be considered for ACEC designation: Sacramento Escarpment (expansion of the current designation), Alkali Lakes area, Cornudas Mountain, Wind Mountain, Alamo Mountain, and Three Rivers. The formal undertakings of the amendment including public involvement will be conducted in midFY 1994.

- Wildlife input was provided for the initial phases of the northeast McGregor Coordinated Resource Management Plan. A vegetation/habitat inventory was initiated, using satellite imagery, to support the development of vegetation management goals and objectives. The inventory is scheduled to be complete in November 1993.

- Conduct an extensive inventory of all riparian areas within the Resource Area to obtain basic biologic and management information, and to rate the condition of each area as functional, functional at risk, or non-functional. Most field work for this project was completed in October 1993.

\section{Planned Actions}

Some of the following actions may be dropped due to lack of funding or personnel to complete them.
- Establish pole planting tests (riparian tree species) in Coyote and San Andres Canyons.

- Survey and design a reroute of the county road in Coyote Canyon in coordination with Otero County, the State Land Office, and New Mexico Department of Game and Fish (NMDGF).

- Conduct an aerial survey of mule deer on the Brokeoff Mountains and Cornucopia Hills in coordination with NMDGF. This is a Sikes Act Project.

- Complete the preparation of the wildlife portion of the north McGregor Coordinated Resource Management Plan and the related vegetation/habitat remote sensing inventory.

- Monitor the Percha Creek riparian area.

- Construct three wildlife water units on the Jornada del Muerto for pronghorn antelope, small game, and non-game species. Survey and design two additional water units. Construction will be done in-house, using volunteer labor. This is a Sikes Act Project.

- Construct two reservoir exclosures on the Jornada del Muerto. Survey and design two additional exclosures. Construction will be done inhouse, using volunteer labor. This is a Sikes Act Project.
- Reconstruct two large rain water catchments on Caballo Mountain using volunteers. This is a combined 8100 and Sikes Act Project.

- Conduct initial testing of the new BLM Special Status Species Tracking Database.

- The NMDGF has proposed a February 1994 pronghorn antelope transplant to augment the existing population in the Jornada del Muerto. We will conduct studies to determine existing population densities, habitat suitability, and habitat capability. The BLM and NMDGF have been coordinating the proposal with area ranches since October 1993. Up to 100 antelope are proposed for release.

- Conduct a fisheries inventory of Tierra Blanca Creek.

- Design an inventory for aplomado falcons on Otero Mesa to characterize habitat and detect use of the area by these falcons.

- Conduct an inventory of willow flycatchers on Tierra Blanca, Percha, and Palomas Creeks following U.S. Fish and Wildlife Service (USFWS) protocol.

- Conduct an aerial inventory of the Texas portion of the gypsum scalebroom population as funding allows. This information will provide perspective in the management of this plant on public land. 
- Construct nine exclosures to monitor the impacts of grazing on gypsum scalebroom as per the Guadalupe Ranch Coordinated Resource Management Plan.

\section{PROGRAM NOTES}

Emphasis within the Caballo Resource Area Wildlife Program is shifting toward the basic management needs of riparian habitats, general habitat conditions on grazing allotments, and management of special status species within the framework of ecosystem management. The existing boundaries between traditional wildlife habitat and special status species management activities and other programs are dissolving, allowing for a truly more interdisciplinary ecosystem approach.

Caballo Resource Area has completed the second year in the Wildlife Pilot District Program. This program has provided increased funding to demonstrate the benefits of improved capability in wildlife and special status species management.

\section{CULTURAL RESOURCES}

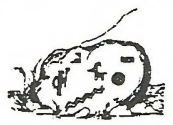

\section{Accomplishments}

- The final session of the Three Rivers Rock Art Recording Field School was completed.
- Completed construction of the Three Rivers Petroglyph Park Fence, including the BLM portion of Three Rivers.

- A contract was awarded to document the several years of field recording at the Three Rivers Petroglyph Site.

- The Lake Valley Cultural Resource Management Plan was completed.

- An Intra-Agency Agreement was initiated between the BLM and the National Park Service for stabilization projects at Lake Valley. Stabilization designs were completed for the schoolhouse and chapel.

- A 4-week project to stabilize the southwest corner of the Lake Valley Schoolhouse was completed.

- Interpretive signs for the Lake Valley Back Country Byway were designed.

- Under guidance of the Caballo Resource Area Archeologist, seven NMSU public history graduate students began work on various projects associated with Lake Valley: a Lake Valley Back Country Byway brochure, a Lake Valley SelfGuided Tour brochure, and a traveling "kit museum" suitable for fourth and fifth grade curriculums.

\section{Planned Actions}

- Finalize the report documenting the Three Rivers Rock Art Field Schools.
- Perform a cultural resources inventory at the Three Rivers Petroglyph Site to record and determine spatial extent and locations of associated archeological sites.

- Continue stabilization of buildings at Lake Valley.

- Publish and implement Lake Valley projects designed by NMSU students.

- Finalize the Caballo Resource Area portion of the Butterfield Trail Cultural Resource Management Plan.

\section{PROGRAM NOTES}

The Caballo Resource Area Cultural Resource Management Program supports the other Resource Area programs by conducting archeological surveys as part of the environmental assessment process. The Resource Area's proactive cultural resources emphasis is on Three Rivers Petroglyph Site and Lake Valley. Three Rivers Petroglyph Site, located in Otero County, north of Alamogordo, is an established public recreation area with picnic facilities, restroom, trails, interpretive signs and brochure, and resident camp. hosts. Lake Valley is an historic mining town in Sierra County and is a major attraction along the recently designated Lake Valley Back Country Byway. 


\section{RECREATION}

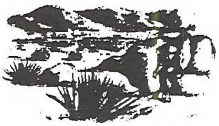

\section{Accomplishments}

- Designation of the Lake Valley Back Country Byway in Sierra County.

- Awarded contract for construction of interpretive road pullouts along the Lake Valley Back Country Byway.

- Awarded contract for construction of the Three Rivers camp host shelter.

- Four Special Recreation Permits were issued and monitored for guide and outfitting, hiking, motorcycle racing, and horse racing.

- Held the McGregor Deer Hunt, 197 deer hunters participated with 61 percent success for deer hunters.

- Held the McGregor Antelope Hunt, 58 antelope hunters participated with 53 percent success.

Annual Hunt Patrol was conducted in FY 1993.

\section{Planned Actions}

- Develop a brochure for Lake Valley Back Country Byway.
- Conduct McGregor deer and antelope hunts in coordination with the NMDGF and the U.S. Army.

- Conduct the annual Hunt Patrol in FY 1994.

- Continue recreation fee collection at Three Rivers Petroglyph Site and Picnic Area.

- Maintain public information signs in the Cornudas area showing off-road vehicle (ORV) limitations.

- Maintain public information signs in the Cuchillo Mountains to show ORV limitations.

- Continue working to improve the access permit system for McGregor Range (with U.S. Army). Work is continuing with the Army to return permit processing to the BLM for all citizens, and to improve convenience and service to the public. At this time, permits are available at the BLM office in Las Cruces for Las Cruces residents; all others must go to Fort Bliss for permits. Once a permit is processed by BLM or the Army, authorized McGregor Range users are to comply with Fort Bliss access rules.

- Maintain interpretive road pullouts and all kiosk/signs in a safe and attractive state.

\section{PROGRAM NOTES}

The Caballo Resource Area, in partnership with the Prairie Dawg
Motorcycle Club of Alamogordo, has been awarded a $\$ 5,000$ grant under the National Recreation Trail Fund (NRTF) program. The grant will be used to fund area improvement projects that will benefit all users.

\section{WILDERNESS}

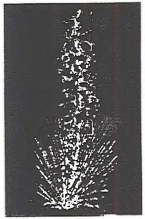

\section{Planned Action}

- Wilderness Study Areas will be patrolled and monitored to ensure compliance with the BLM's Interim Management Policy.

\section{PROGRAM NOTES}

WSAs will continue to be managed in compliance with the Interim Management Policy and Guidelines for Land Under Wilderness Review. The Brokeoff Mountains WSA encompassing 31,386 acres and the Culp Canyon WSA encompassing 10,937 acres have been signed and are monitored every other month. The southern portion of the Jornada del Muerto that extends into Sierra County is also monitored. 


\section{Accomplishments}

- Conducted patrol activities in Sierra and Otero Counties, including McGregor Range.

Resource Area activities consisted of 263 days of patrol and contacts with over 1,700 public land users.

- Conducted enforcement activities, including 82 written and verbal warnings and 4 citations issued.

\section{Planned Action}

- Continue to conduct patrol activities in the areas of public land that see the most use and frequency of unauthorized use, and conduct investigations as needed.

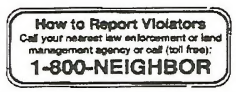

\section{PROGRAM NOTES}

The activities that are most focused upon by the Rangers in their patrols include damage and theft to archaeological/historical sites, mineral material theft, recreational activities including off-road vehicles and hunting, illegal trash and hazardous materials dumping, and denial of access to public land. 


\section{CABALLO RESOURCE AREA \\ ENVIRONMENTAL ASSESSMENTS \\ FISCAL YEAR 1993}

\begin{tabular}{|c|c|c|}
\hline NUMBER & EA NAME & $\begin{array}{c}\text { DATE } \\
\text { COMPLETED }\end{array}$ \\
\hline$N M-037-93-001$ & Escondida Tank & $23-$ Oct -92 \\
\hline$N M-037-93-002$ & Hay Meadow Fire Rehabilitation & $18-$ Nov -92 \\
\hline$N M-037-93-003$ & Hille Well & $24-$ Nov -92 \\
\hline$N M-037-93-004$ & Stewart Pipelines & $24-$ Nov -92 \\
\hline NM $-037-93-005$ & Holloman Air Force Base - 1 & $03-$ Dec-92 \\
\hline$N M-037-93-006$ & Water Well Canyon & $18-$ Dec -92 \\
\hline NM $-037-93-007$ & Mine Shaft Well & $18-$ Dec -92 \\
\hline$N M-027-93-008$ & McGregor Range Unit \#8 & $13-$ Oct -92 \\
\hline$N M-037-93-009$ & $\begin{array}{l}\text { U.S. West Communications } \\
\text { Buried Cable ROW }\end{array}$ & $28-\operatorname{Dec}-92$ \\
\hline NM $-037-93-010$ & Sierra Electric Coop. Torres Ranch & $12-$ Jan -93 \\
\hline$N M-037-93-011$ & NMSHTD Free Use Permit & $03-\mathrm{Feb}-93$ \\
\hline NM $-037-93-012$ & Otero County Electric Cooperative & $28-$ Jan -93 \\
\hline$N M-037-93-013$ & Canalejas Canyon Improvements & $11-$ Feb -93 \\
\hline NM $-037-93-014$ & Holloman Air Force Base & $28-\mathrm{Jan}-93$ \\
\hline$N M-037-93-015$ & Oil and Gas Lease Sale Parcels & $01-\mathrm{Jan}-93$ \\
\hline$N M-037-93-016$ & Pickard Fence & $23-\mathrm{Feb}-93$ \\
\hline NM $-037-93-017$ & Golondrina Pipeline Permit (Section 4) & $03-$ May -93 \\
\hline $\mathrm{NM}-037-93-018$ & High Lonesome Pipelime & $03-\mathrm{Mar}-93$ \\
\hline NM $-037-93-019$ & Flying X Burn & $17-\mathrm{Mar}-93$ \\
\hline $\mathrm{NM}-037-93-020$ & R. C. Tank Pipeline and Storage & 29-Mar-93 \\
\hline$N M-037-93-021$ & Lake Valley Backcountry & $06-\mathrm{Apr}-93$ \\
\hline NM $-037-93-022$ & Sierra Valley Construction & $24-$ May -93 \\
\hline $\mathrm{NM}-037-93-023$ & $\begin{array}{l}\text { Change in Kind of Livestock From } \\
\text { Cattle to Bison }\end{array}$ & $08-\mathrm{Jul}-93$ \\
\hline$N M-037-93-024$ & INS/DOJ/Border Patrol Communication Site & $15-\mathrm{Jul}-93$ \\
\hline$N M-037-93-025$ & Prelo Access - ROW & $14-\mathrm{Jul}-93$ \\
\hline$N M-037-93-026$ & Brushy Catchment Reconstruction & $14-J u l-93$ \\
\hline$N M-037-93-037$ & Highway Fence Turnout & $21-J u 1-93$ \\
\hline $\mathrm{NM}-037-93-038$ & Hunter Pipeline & $21-J u l-93$ \\
\hline$N M-037-93-039$ & $\begin{array}{l}\text { Lake Valley Schoolhouse and } \\
\text { Chapel Stabilization }\end{array}$ & $28-J u l-93$ \\
\hline $\mathrm{NM}-037-93-040$ & Lewis Corrals and Pipeline & $21-J u l-93$ \\
\hline$N M-037-93-041$ & Border Patrol Drag Road System ROW & 18-Aug-93 \\
\hline$N M-037-93-042$ & $\begin{array}{l}\text { Oil and Gas Lease Parcels } \\
\text { (U.S. Forest Service) }\end{array}$ & $23-$ Aug -93 \\
\hline
\end{tabular}

NOTE: EA Nos. 027 through 036 were inadvertently omitted in the numbering process. 

APPENDIX B

RANGE IMPROVEMENTS IMPLEMENTED IN FY 1993

AND PR OPOSED FOR FY 1994

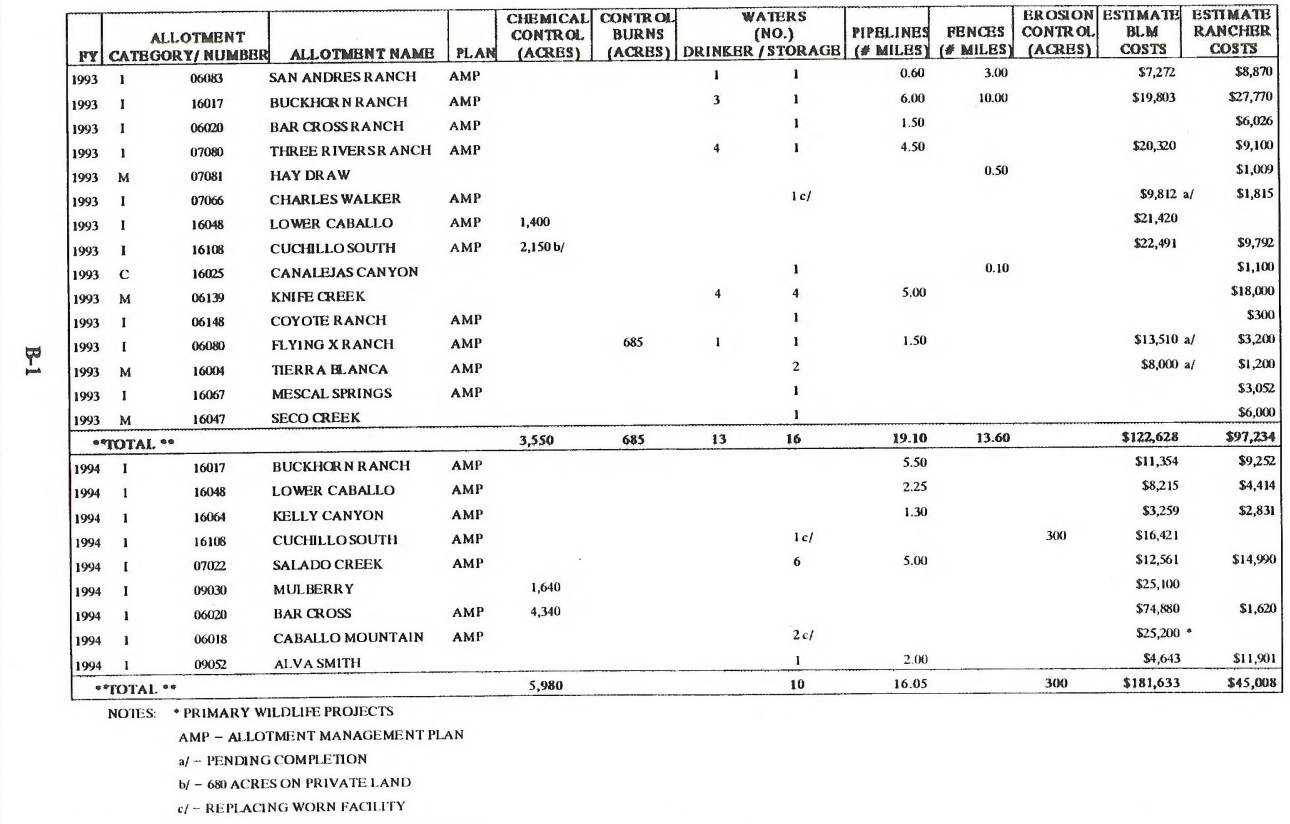




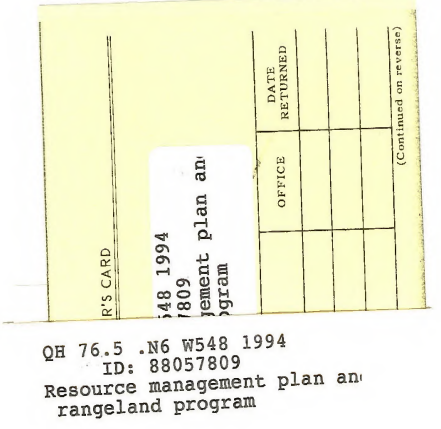

BUREAU OF LAND MANAGEMENT LIBRARY
BLDG. 50, ST-136
DENVER FEDERAL CENTER
P.O. BOX 25047
DENVER, COLORADO 80225 


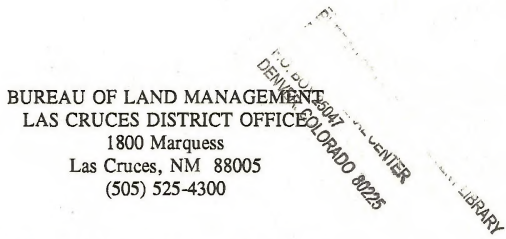

CABALLO RESOURCE AREA

Timothy M. Murphy Area Manager

Corina Pacheco

John Weiner

Rocky Arries
Ranger

Ranger
Staff Assistant
525-4372

525-4375

$525-4406$

$525-4307$

RANGE STAFF

Miles Brown

Supervisory Range Conservationist

$525-4315$

Betts Donaldson

Range Clerk

$525-4330$

Ray Aguilar

Range Conservationist

$525-4301$

James Christensen

Range Conservationist, McGregor Range

$525-4322$

Doug Coalson

Range Conservationist

$525-4323$

Eli Gutierrez

Maintenance Worker, McGregor Range

$525-4322$

Range Conservationist

$525-4362$

Range Conservationist

$525-4377$

Tom Phillips

Range Conservationist, McGregor Range

525-4392

\section{MULTI-RESOURCES STAFF}

Tim Sanders

Bernie Creager

Margie Guzman

Theresa Hanley

Mike Howard

Lorraine Salas

Roy Placker

Joe Sanchez

Judith Waggoner
Multi-Resources Staff Chief

Realty Specialist

Wildlife Biologist

Archeologist

Lead Wildlife Biologist

Realty Special ist

Wildlife Biologist

Natural Resource Specialist

Realty Special ist
525-4393

525-4325

525-4339

$525-4342$

525-4348

525-4388

525-4379

525-4391

525-4403 
UNITEI) STATES

I)EI'ARTMENT OF THE INTERIOR

BURLAU(F I.ANI) MANAC IEMFNI

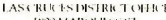

Fro MARLA IE:S S1

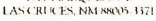

GHF IAI BKINAS

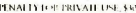

DSC LIBRARY

BLDG 50 DENVER SERVICE CTR

DENVER, CO 80225 